\title{
Understanding the Links Between the Climate Crisis and Child Health
}

\section{Iiklim Krizi ve Çocuk Sağlığı Arasındaki illişkiyi Anlamak}

\author{
Yakup Gözderesi ${ }^{1^{*}}{ }^{(\mathbb{D}}$, Enis Hikmet Özmert ${ }^{2^{*}}$ (1)
}

\author{
${ }^{1}$ Marmara University, Faculty of Medicine, Istanbul, Turkey \\ ${ }^{2}$ Baskent University, Faculty of Medicine, Ankara, Turkey \\ "Co-author
}

ORCID ID: Y.G. 0000-0003-4229-6391; E.H.Ö. 0000-0001-6510-305X

Citation/Attf: Gozderesi Y, Ozmert EH. Understanding the links between the climate crisis and child health. Çocuk Dergisi - Journal of Child 2021;21(3):281287. https://doi.org/10.26650/jchild.2021.990189

ABSTRACT

Climate change has severe adverse effects on both child and adult health. It affects multiple body systems including the respiratory, immunologic, and neurologic systems. Increased temperatures, water and food insecurity, extreme climate events such as heatwaves and a loss of biodiversity all increase the prevalence of infectious and non-communicable disease.

ISSOP is an international organization that works with social pediatrics and child health professionals in areas of health promotion, disease prevention, curative pediatrics and rehabilitation through participation in system development, policy-making processes and the publishing of international documents for guidance.

The "Responding to the Impact of Climate Change on Children" webinar series is a global initiative that aims to highlight the importance of climate change and its adverse effects on child health. Eight structured two-hour webinars were held between February and September 2021.

In this review, we aim to summarize the topics of the webinar series and provide recommendations to child health professionals which they can use in their academic and clinical practices. The consequences of climate change on health and, more specifically, child health, deepening inequalities and inequities, the essential role of youth, and the integration of climate change into health education will be discussed.

Climate change is a public health emergency and requires everyone to take action. Healthcare professionals, as members of a respected and trusted occupation, must be made aware of the negative health consequences of climate change and play an informative role in society. The impact of such consequences that affect children's health can be mitigated by increasing societal awareness of the effects of climate change, taking the relevant precautions and implementation of mitigation and adaptation strategies by parents and pediatricians.

Keywords: Social pediatrics, child health, climate change, ISSOP öz

İklim değişikliğinin hem çocuk hem de yetişkin sağlı̆̆ı üzerinde ciddi etkileri bulunmaktadır. İklim değişikliğinin vücuttaki etkileri, solunum sistemi, sinir sistemi ve bağışıkıı sistemi dâhil olmak üzere birçok vücut sisteminde ortaya çıkmaktadır. Sıcaklık artışı, temiz su ve gıdaya erişimdeki yetersizliklerle birlikte biyoçeşitliliğin azalması ve sıcak hava dalgaları gibi olağandışı iklim olayları, bulaşııı hastalıklarla birlikte, bulaşııı olmayan hastalıkların görülme sıklığını artırmaktadır. ISSOP(Uluslararası Sosyal Pediatri Derneği), sosyal pediatristlerle ve çocuk sağ|ığı profesyonelleriyle birlikte, sağlığın korunması ve geliştirilmesi, hastalıkların önlenmesi, tedavi ve rehabilitasyon alanlarında çalışan, bunu yönetim sistemlerine ve politika yapım süreçlerine katıım sağlama ve rehber dokumanlar yayınlama yoluyla yapan uluslararası bir dernektir. "iklim Değişikliğinin Çocuklar Üzerindeki Etkisine Karşılık Verebilmek” seminer serisi, ISSOP'un iklim değişikliğinin önemini ve çocuk sağlığı üzerindeki olumsuz etkilerini öne çıkarmayı amaçlayan küresel bir girişimidir. Bu kapsamda 2021 yılının Şubat ve Eylül ayları arasında ikişer saatlik sekiz yapılandırılmış seminer düzenlendi. Bu derlemede, seminer serisinin konuları özetlenerek çocuk sağlığı profesyonellerine akademik ve klinik uygulamalarında kullanabilecekleri öneriler sunulmaktadır. İklim değişikliğinin özellikle çocuk sağlı̆̆ı üzerindeki etkileri, iklim değişikliği kaynakı ırtan eşitsizlik ve adaletsizlikler, gençlerin iklim değişikliğine verilen yanıttaki temel rolü ve iklim değişikliğinin sağlık eğitimine entegrasyonu tartışılacaktır. İklim değişikliği bir halk sağlığı acilidir ve herkesin harekete geçmesini gerektirmektedir. Sağıı profesyonelleri, toplum tarafından saygı ve güven duyulan bir mesleğin üyeleri olarak, iklim değişikliğinin olumsuz sağlık sonuçlarından haberdar olmalı ve toplumda bilgilendirici bir rol oynamalıdır. Bu sonuçların çocuk sağıı̆ı̆ı olumsuz etkileri, iklim değişikliğine ilişkin toplumsal farkındalığın artıııması, ilgili önlemlerin alınması, ebeveynlerin ve çocuk sağlığı profesyonellerinin iklim değişikliği uyum ve azaltım stratejilerini uygulaması yoluyla hafifletilebilir.

Anahtar Kelimeler: Sosyal pediatri, çocuk sağı̆ğı, iklim değişikliği, ISSOP

Corresponding Author/Sorumlu Yazar: Yakup Gözderesi E-mail: yakupgozderesi@gmail.com

Submitted/Başvuru: 02.09.2021 • Revision Requested/Revizyon Talebi: 30.09.2021 • Last Revision Received/Son Revizyon: 01.11.2021 •

Accepted/Kabul: 02.11.2021 


\section{INTRODUCTION}

The recently published Sixth Assessment Report of the Intergovernmental Panel on Climate Change (IPCC) of the United Nations paints a dire image as to the state of climate change. It strongly asserts that anthropogenic greenhouse gas emissions, primarily caused by the burning of fossil fuels, have contributed enormously to an increase in annual average temperatures around the globe (1). The IPCC report estimates that by the 2030s, there will be an increase in global surface temperature of approximately $1.5^{\circ} \mathrm{C}$, as compared to the preindustrial era (1).

The effects of these projected changes are already visible from the increase in numbers and severity of communicable and non-communicable diseases. These NCDs include cancer, cardiovascular diseases, autoimmune disorders, diabetes, neurologic diseases and many more (2). Climate change also has many adverse effects on the social determinants of health. Social Determinants of Health (SODHs), as defined by the World Health Organization (WHO), are "the social circumstances in which people are born, grow, live, work, and play, profoundly affect children's health and drive health disparities" (3). Climate change exacerbates the effects of SODHs, such as, but not limited to, food insecurity, air and water pollution and access to healthcare (4). SODHs contribute to NCD prevalence worldwide, including socioeconomic status, health systems, gender, ethnicity, and disability status. For instance, adverse environmental events, social conditions, and exposures to pollutants affect people's psychological status. People living under these conditions, turn to unhealthy coping mechanisms like smoking and drinking alcohol, which contribute to inequalities in NCDs (5).

NCDs are a major cause of death worldwide and account for more than $70 \%$ of all deaths globally per year. Climate change directly contributes to increases in NCDs such as obesity, heat strokes, and mental health issues. Negative effects on the living environment, a social determinant of health, also contribute to poorer health outcomes in children. As an example, air pollution, caused by excess burning of fossil fuels, adversely affects fetal development, neurodevelopment and respiratory health in childhood (6). Therefore, child health professionals play an essential role in the prevention of NCDs (7).

Furthermore, certain parts of the globe have seen the emergence of infectious diseases in previously unaffected areas and an increased risk of disease in areas where the disease is already present (8). In this regard, health professionals have an active role to play in mitigating the effects of climate change and advocating for the implementation of policies and measures that address these effects (9). Healthcare professionals have fundamental roles in public health and health promotion as they are authorities for valid, scientific, evidence-based information (10).

The Paris Agreement on Climate Change that was signed by 195 countries came into effect in 2016. The overarching goal of the agreement is to keep the increase in global average temperature below $2^{\circ} \mathrm{C}$ and potentially, under $1.5^{\circ} \mathrm{C}$ (11). One drawback of the agreement is that although it establishes a clear goal, it doesn't provide a roadmap to achieve this goal, and instead expects each country to create their own guidelinestermed Nationally Determined Contributions (NDC). When these NDCs were examined, it was found that although $73 \%$ of countries had mentioned health in their national plan, only $22 \%$ had specific health adaptation plans (12). Furthermore, according to UNICEF, "Only $42 \%$ of all Nationally Determined Contributions (NDCs) contain direct reference to children or youth while only $20 \%$ mention children specifically" (13). In this regard, the global community has a great amount of work to do to address the impact of climate change on health, and especially child health.

Social pediatrics is a holistic and inclusive approach to child health and well-being, including relations of children with the environment, society, school and family (14). ISSOP (International Society for Social Pediatrics and Child Health), established in 2012, as a continuation of ESSOP (European Society for Social Pediatrics and Child Health, 1977-2011), is a non-profit organization, registered in Geneva. The organization convenes health professionals and organizations to share their experience and knowledge in social pediatrics and the child health field (15). ISSOP's main scopes are health promotion, disease prevention, curative pediatrics, and rehabilitation (16).

ISSOP's declaration "Responding to the Impact of the Climate Crisis on Children and Youth" explains and emphasizes the importance of the roles of child health professionals in the mitigation of climate change's negative effects (17). ISSOP invites every child's health provider and advocate to take action in the mitigation of the direct and indirect consequences of climate change on child health.

\begin{abstract}
"Responding to the Impact of Climate Change on Children" a global ISSOP webinar series, convened international experts on sustainability, eco-anxiety, green politics and economics, social and health aspects of climate change. There have been eight structured two-hour meetings held from February to September 2021. The series aimed to create a platform for participants to discuss the impact of climate change on child health and generate discussions on actions they can take now and in the future. Based on the information gathered from the regional break-out sessions, a climate change strategy for child health professionals will be developed.
\end{abstract}

\section{Climate change has severe consequences for our environment and the ecosystem, impacting health}

Reports state that the increase in greenhouse gas emissions since the late $19^{\text {th }}$ century is due to human activity. It further reaffirms that the globe has warmed by $1.2^{\circ} \mathrm{C}$ since the $19^{\text {th }}$ century and is likely that it will warm by $2^{\circ} \mathrm{C}$ in the coming 20 years. Moreover, humans are most likely the cause of glacier melting and warming of oceans. Warmer temperatures also change the life cycle of aquatic animals (18). Also, human intervention due to excessive burning of fossil fuels throughout the last two centuries further adds to climate change by 
introducing greenhouse gasses to the atmosphere and exacerbating air pollution.

Climate change also increases the severity and incidence of extreme weather events such as floods, droughts, hurricanes, and heat waves. Not only do these events have the ability to restrict access to healthcare services and facilities, they also negatively impact many of the social determinants of health, increasing morbidity and mortality.

Along with a changing climate, rising surface temperature, habitat loss and changing weather patterns, pressure on food systems increases. Work towards ending undernutrition and hunger has yielded great results in the past few decades. The amount of undernourished people decreased from 980 million worldwide in the 1990 s to 850 million in the 2010s (19). However, this progress may be hindered by climate change. Climate change places a great burden on the agriculture, fisheries and livestock industries. Crop yields and the nutrients in crops may fluctuate, creating a volatile environment of basic nutrient insecurity. Due to acidification of oceans, along with other factors, yields in fisheries may decrease. Livestock productivity may also decrease (20). Furthermore, these effects may not be felt equally, affecting primarily disadvantaged populations.

Water systems are already affected due to climate change. Stress put on water resources from overuse in industry, agriculture, and power generation; coupled with increasingly inconsistent weather patterns and higher evaporation rates will lead to water scarcity in some regions of the globe. According to UNICEF, "nearly 160 million children are currently living in areas under high or extremely high drought severity" (21).

\section{Climate change affects many different aspects of human health and wellbeing}

Climate change affects different systems of the human body such as the respiratory, allergic, immunologic and neurologic systems (22).

The altered profile of antigens and gut microbiota change because of dysbiosis, and the biodiversity loss causes an increased rate of allergic diseases (22). People are also at risk of Zinc-deficiency because higher elevated levels of $\mathrm{CO}_{2}$ reduce the nutritional content of plant-based foods (23).

Vector-borne communicable diseases are of particular importance in the climate change discourse, as the prevalence of the diseases spread by vectors are affected by the environment and the climate. These diseases also worsen the overall health outcomes of a community and exacerbate health inequalities (24). The incidence of malaria in higher altitudes is increasing in the tropical regions. Zika, West Nile, chikungunya and yellow fever are all affected by the impacts of climate change (25). Tick-borne diseases such as Crimean Congo hemorrhagic fever and Lyme disease are also affected by the changes in climate.

Considering these effects of climate change, children are a vulnerable group. They are at risk from the adverse health effects of climate change and face more negative consequences that affect different body systems such as cardiovascular, respiratory, and immune systems. Heat-waves caused by climate change increase direct morbidity from heatstroke, electrolyte imbalance, pediatric kidney stones, Kawasaki disease, respiratory and infectious diseases in children (26). In addition to heat waves, cold temperatures and rapid temperature change induce respiratory and infectious diseases in children (26).

As a consequence of climate change, the duration and intensity of the pollen season has changed. Because pollen allergens trigger inflammatory mediators, it causes Ig-E mediated sensitization and increasing rates of asthma (27).

Climate change affects people's mental health negatively. Increases in cases of mood disorders and anxiety, posttraumatic stress disorders, sleep disruption, and suicidal ideation rates are the results of climate change and related events (28). Children living in developing countries are especially vulnerable to these effects (29).

\section{Climate change amplifies present and inherent inequalities}

The environmental impact of climate change, such as elevated temperatures, excess unnatural precipitation or, conversely, droughts, extraordinary weather events, and increased sea levels, affect each social group differently. Social groups such as women, children, indigenous people, and workers are more exposed to the negative consequences of climate change (30, 31).

For example, the Saami people, the indigenous people of Northern Scandinavia, have experienced shortened snow cover days, loss of pasture land and ecosystem changes as negative consequences of climate change. Negative consequences of climate change also include alterations in the ecological base of the Saami people, chronic disease mortality, asthma, and allergies. Additionally, the cultural well-being status of the community is being affected (32).

Women are more affected by adverse effects of climate change, such as extreme weather events and natural disasters, especially in low-income countries (30). It induces negative reproductive effects, nutritional deficiency, and health problems during pregnancy. Additionally, there is a higher rate of sexual violence against women as a result of climate change (33).

Children are also affected by climate change in different ways, such as a decreased psychological well-being, higher respiratory and infectious disease rates and an increased risk of malnutrition $(34,35)$.

In addition to mental health diseases like depression, anxiety and PTSD, emotional problems and behavioral changes may be observed (26). As children show a higher interest and concern about climate change, they will increasingly demonstrate increases in mental health issues such as guilt, sadness, and difficulty concentrating (36). 


\section{What can child health professionals do to reduce the impact of climate change?}

a) Inclusion of the voices of diverse youth groups is essential in creating policies and dialogues against climate change The ideas of diverse groups of youth is an essential resource for child health professionals. Starting in the 1990s and gaining momentum, youth activism against climate change has established itself as a driving force against climate change (37). Through organizations such as Fridays For Future (started by Greta Thunberg from Sweden in 2018), the UN, and through legal means (38), the youth of today have an increased ability to voice their concerns and provide their perspectives in the climate change debate.

Climate change is a complex issue which establishes different priorities, impacts and approaches depending on the region. A diverse group of youth is needed to engage in climate change discourse. Some countries provide better opportunities for youth to be involved in decision making and organizing in terms of climate change. As such, there might be an imbalance in representing many different countries and factions inside the country. Ethnic minorities, lower income households and refugees are disproportionately affected by climate change (39). However, those same groups, especially ethnic minorities, also have a lower response rate for national surveys assessing the impact and mitigation strategies for climate change (40). Even though the disadvantaged groups are the groups most impacted by the effects of climate change, they are not equally represented in policy decisions. Programs aimed at studying the impact of climate change and establishing policies should aim to empower youth.

b) There is an active need for inclusion of climate change in health education and healthcare

Medical professionals need to be equipped with the knowledge and expertise to address the broad scope of health issues impacted by climate change, including making their practices greener.

Although there are programs, seminars and classes focusing on climate change, the degree to which it is discussed varies widely between health profession institutions (41). There is also a need to develop curricula focused on climate change (41). In a survey carried out with medical students, $90 \%$ of respondents identified their role in tackling climate change, but $80 \%$ of them also admitted to lacking information regarding climate change and health (42).

Healthcare activities are a major contributor to climate change, with the US healthcare system accounting for 9-10\% of greenhouse emissions each year (43). So, it is vital for medical professionals to rethink how healthcare is thought of, structured, and delivered. In the US, $25 \%$ of healthcare spending is wasted (44). Initiatives like "My Green Doctor", started by a healthcare professional for healthcare professionals establishes the groundwork for a paradigm shift as to how healthcare professionals approach climate change. Assessing how a healthcare practice impacts the environment and what steps can be taken to minimize the impact is an excellent place to start. Larger healthcare hubs should rethink how supplies are utilized to create more sustainable working environments. Medical professionals need to start thinking about how their actions impact the environment and what they can do to minimize the impact.

c) ISSOP invites all child health specialists to act against the unfavorable effects of the climate crisis on child health

ISSOP's declaration titled "Responding to the Impact of the Climate Crisis on Children and Youth" aims to explain and underline the vital roles of child health professionals and organizations in achieving climate justice. ISSOP advocates that the climate crisis is a child rights crisis in this declaration (17).

The declaration recommends:

- Promoting the education of child health professionals, elected officials, communities, children and parents in several topics related to climate change and mitigation strategies.

- Advocacy as an occupation the society trusts. Through the framework of anticipatory guidance, child health professionals should discuss climate change with parents during medical visits.

- To act on developing local, national, and international policies and strategies for reducing greenhouse gas emissions and to be prepared for the negative consequences of the climate crisis.

Additionally, child health professionals should reject the sponsorship of fossil fuel and baby food industries in meetings, stop the commercial exploitation of children and mitigate its impact on consumerism throughout the life course.

ISSOP calls for every child health specialist and everyone to act in the prevention and mitigation of the direct and indirect impacts of the climate crisis on the health and well-being of children and youth.

\section{CONCLUSION \& RECOMMENDATIONS}

Climate change has severe adverse health consequences throughout the life course. It is a planetary health emergency, because it affects not only human beings' lives but also damages the environment and habitus. Climate change affects human health and wellbeing in a variety of aspects and amplifies present inequalities. As such, child health professionals have a role in mitigating the effects of climate change and creating a forum for discussion. This can be achieved through discussing the issue with diverse groups of youth, embedding climate change into health education, and considering how healthcare can be revolutionized to combat climate change. These values culminated in the ISSOP's declaration regarding the matter, wherein it invites all child health specialists to act against the untoward effects of the climate crisis on child health.

After the eight sessions of the ISSOP webinar series titled "Responding to the Impact of Climate Change on Children", 
the science of climate change, health systems integration in greening practices, pediatrics and one health, COP 26 and child health policies, adverse health and mental health effects of climate change, the political and economic impact of climate change have been discussed.

Through the aforementioned discussion and investigation of the available literature, we recommend the following as guiding principles in addressing climate change at home and in healthcare settings:

- Explore the science behind climate change and make deductions based on the latest scientific research to guide your practice and shape your understanding of the issue.

- Investigate how your daily lifestyle choices related to the use of fossil fuels may be impacting the planet, from the modes of transport you choose to the sources of heating and electricity you utilize.

- Explore how you and your healthcare practice may be impacting the environment and try to mitigate the effects as much as you can.

- Use your position as a healthcare provider to advocate for local and national governments to act on different aspects of climate change and enact law/regulations to that effect.

- Encourage and lobby your healthcare center to rethink how they approach management of medical supplies, waste and energy in order to create a more sustainable healthcare service.

- Engage a socioeconomically, ethnically and culturally diverse group of youth to extract key ideas and concepts on how policies can be shaped and communicated in order to better address climate change and the problems it creates for youth.

- Produce materials that include the essential information about the climate crisis and how parents can act, and distribute them after medical visits as a part of the anticipatory guidance framework.

- Use plastic-free materials in your examination rooms and decrease your carbon footprint.

- Advocate for the inclusion of climate change and related topics in the medical curricula and ensure medical students are made aware and informed about climate change and its effects on health.

- Create a space for discussion in your professional network on how to organize more sustainable meetups, conferences and seminars by reducing the travel needed, and innovating to minimize waste and carbon footprint of the event.

- Act with civil society and other stakeholders in the community for a broader reach and understanding among people.

Acknowledgment: Thanks to Prof. Dr. Perran Boran for her mentorship during the study. Thanks to Dr. Nick Spencer for giving us this opportunity, and thanks a lot to all ISSOP for organising the webinar series.
Informed Consent: Written consent was obtained from the participants.

Peer Review: Externally peer-reviewed.

Author Contributions: Conception/Design of Study- Y.G., E.H.Ö.; Data Acquisition- Y.G., E.H.Ö.; Data Analysis/Interpretation- Y.G., E.H.Ö.; Drafting Manuscript- Y.G., E.H.Ö.; Critical Revision of Manuscript- Y.G., E.H.Ö.; Final Approval and Accountability- Y.G., E.H.Ö.

Conflict of Interest: Authors declared no conflict of interest.

Financial Disclosure: Authors declared no financial support.

Teşekkür: Çalışma boyunca bize yol gösterici olduğu için Prof. Dr. Perran Boran'a teşekkür ederiz. Ayrıca bize bu firsatı verdiği için Dr. Nick Spencer'a, seminer serisini organize eden ISSOP'a ve emeği geçenlere çok teşekkür ederiz.

Bilgilendirilmiş Onam: Katılımcılardan bilgilendirilmiş onam alınmıştır.

Hakem Değerlendirmesi: Dış bağımsız.

Yazar Katkıları: Çalışma Konsepti/Tasarım- Y.G., E.H.Ö.; Veri ToplamaY.G., E.H.Ö.; Veri Analizi/Yorumlama- Y.G., E.H.Ö.; Yazı Taslağı- Y.G., E.H.Ö.; İçeriğin Eleştirel İncelemesi- Y.G., E.H.Ö.; Son Onay ve Sorumluluk- Y.G., E.H.Ö.

Çıkar Çatışması: Yazarlar çıkar çatş̧ması beyan etmemişlerdir.

Finansal Destek: Yazarlar finansal destek beyan etmemişlerdir.

\section{REFERENCES}

1. Masson-Delmotte V, Zhai P, Pirani A, Connors SL, Péan C, Berger S, et al. IPCC, 2021: Climate Change 2021: The Physical Science Basis. Contribution of Working Group I to the Sixth Assessment Report of the Intergovernmental Panel on Climate Change, Cambridge University Press. In Press.

2. Hashim JH, Hashim Z. Climate Change, Extreme weather events, and human health implications in the Asia Pacific Region. AsiaPacific journal of public health 2016;28(Suppl 2):8S-14S. https:// doi.org/10.1177/1010539515599030

3. International Conference on Primary Health Care (1978: AlmaAta, USSR), World Health Organization \& United Nations Children's Fund (UNICEF). (1978). Primary health care: report of the International Conference on Primary Health Care, Alma-Ata, USSR, 6-12 September 1978 / jointly sponsored by the World Health Organization and the United Nations Children's Fund. World Health Organization.

4. Ragavan MI, Marcil LE, Garg A. Climate Change as a Social Determinant of Health. Pediatrics 2020;145(5):e20193169. doi. org/10.1542/peds.2019-3169

5. Marmot M, Bell R. Social determinants and non-communicable diseases: time for integrated action. BMJ (Clinical research ed.), 2019; 364: I251. https://doi.org/10.1136/bmj.1251

6. Vrijheid M, Casas $M$, Gascon M, Valvi D, Nieuwenhuijsen M. Environmental pollutants and child health-A review of recent concerns. Int J Hyg Environ Health 2016;219(4-5):331-42. doi: 10.1016/j.ijheh.2016.05.001 
7. Proimos J, Klein JD. Noncommunicable diseases in children and adolescents. Pediatrics 2012;130(3):379-81. doi: 10.1542/ peds.2012-1475

8. Wu X, Lu Y, Zhou S, Chen L, Xu B. Impact of climate change on human infectious diseases: Empirical evidence and human adaptation. Environment International 2016;86:14-23. https:// doi.org/10.1016/j.envint.2015.09.007

9. Yang L, Liu C, Hess J, et al. Health professionals in a changing climate: protocol for a scoping review. BMJ Open 2019;9:e024451. doi:10.1136/ bmjopen-2018-024451

10. Zenzano T, Allan JD, Bigley MB, et al. The roles of healthcare professionals in implementing clinical prevention and population health. Am J Prev Med 2011;40(2):261-7.http://dx.doi.org/10.1016/j. amepre.2010.10.023.

11. Bhore SJ. (2016). Paris Agreement on Climate Change: A Booster to Enable Sustainable Global Development and Beyond. International Journal of Environmental Research and Public Health 2016;13(11): 1134. https://doi.org/10.3390/ijerph13111134

12. Dasandi N, Graham H, Lampard P, Jankin Mikhaylov S. Engagement with health in national climate change commitments under the Paris Agreement: a global mixed-methods analysis of the nationally determined contributions. The Lancet. Planetary Health 2021;5(2):e93-e1011ttps://doi.org/10.1016/S2542-5196(20)30302-8

13. Pegram J, Colon C. Are climate change policies child-sensitive? A Guide for Action: Summary. United Nations Children's Fund 2019. Available from: URL: https://www.unicef.org/globalinsight/ media/646/file/are-climate-change-policies-child-sensitive-2019.pdf

14. Spencer N, Colomer C, Alperstein G, Bouvier P, Colomer J, Duperrex $\mathrm{O}$, et al. Social paediatrics. J Epidemiol Community Health 2005;59(2):106-8. doi: 10.1136/jech.2003.017681.

15. International Society for Social Pediatrics and Child Health website, last reach: 06.07.2021, Available from: URL: https://www.issop. org/2018/10/21/who-we-are/

16. International Society for Social Pediatrics and Child Health Presentation Booklet 2018, ISSOP's website, last reach: 06.07.2021, available from: URL: https://www.issop.org/cmdownloads/issoppresentation-2018/

17. ISSOP declaration on climate change, International Society for Social Pediatrics and Child Health website, last reach: 01.08.2021, Available from: URL: https://www.issop.org/2021/03/28/issopdeclaration-on-climate-change/

18. Doney S, Rosenberg AA, Alexander M, Chavez F, Harvell CD, Hofmann G, et al. 2014: Ch. 24: Oceans and Marine Resources. Climate Change Impacts in the United States: The Third National Climate Assessment, J. M. Melillo, Terese (T.C.) Richmond, and G. W. Yohe, Eds., U.S. Global Change Research Program, 557-578. doi:10.7930/JORF5RZW.

19. Wheeler $T$, von Braun J. Climate change impacts on global food security. Science 2013;341(6145):508-13. doi: 10.1126/ science. 1239402.

20. Myers SS, Smith MR, Guth S, Golden CD, Vaitla B, Mueller ND et al. Climate Change and Global Food Systems: Potential Impacts on Food Security and Undernutrition. Annual Review of Public Health 2017;38:259-77. https://doi.org/10.1146/annurevpublhealth-031816-044356

21. Bruntland G, El-Ashry M, Figueres C, Huq S, Knox J, MacCracken M et al. Unless we act now, The impact of climate change on children Report, November 2015. UNICEF Available from: URL: https:// www.unicef.org/media/60111/file
22. Ray C, Ming X. Climate Change and Human Health: A Review of Allergies, Autoimmunity and the Microbiome. Int J Environ Res Public Health 202;17(13):4814. doi: 10.3390/ijerph17134814.

23. Ciesielski T. Climate Change and Public Health: A Small Frame Obscures the Picture. NEW SOLUTIONS: A Journal of Environmental and Occupational Health Policy 2017;27(1):8-11. doi:10.1177/1048291117691075

24. Campbell-Lendrum D, Manga L, Bagayoko M, Sommerfeld J. Climate change and vector-borne diseases: what are the implications for public health research and policy? Philos Trans R Soc Lond B Biol Sci 2015;370(1665):20130552. doi: 10.1098/rstb.2013.0552.

25. Caminade C, McIntyre KM, Jones AE. Impact of recent and future climate change on vector-borne diseases. Ann N Y Acad Sci 2019;1436(1):157-73. doi: 10.1111/nyas.13950.

26. Helldén D, Andersson C, Nilsson M, Ebi KL, Friberg P, Alfvén T. Climate change and child health: a scoping review and an expanded conceptual framework. The Lancet. Planetary Health 2021;5(3):e164-e175. https://doi.org/10.1016/S2542-5196(20)30274-6

27. D’Amato G, Chong-Neto HJ, Monge Ortega OP, Vitale C, Ansotegui $\mathrm{I}$, Rosario N, et al. The effects of climate change on respiratory allergy and asthma induced by pollen and mold allergens. Allergy 2020;75(9):2219-28. doi: 10.1111/all.14476.

28. Palinkas LA, Wong M. Global climate change and mental health. Curr Opin Psychol 2020;32:12-6. doi: 10.1016/j. copsyc.2019.06.023.

29. Majeed H, Lee J. The impact of climate change on youth depression and mental health. Lancet Planet Health 2017;1(3):e94-e95. doi: 10.1016/S2542-5196(17)30045-1.

30. Levy BS, Patz JA. Climate Change, Human Rights, and Social Justice. Ann Glob Health 2015;81(3):310-22. doi: 10.1016/j. aogh.2015.08.008.

31. Jones R. Climate change and Indigenous Health Promotion. Glob Health Promot 2019;26(3_suppl):73-81. doi: 10.1177 /1757975919829713.

32. Jaakkola JJK, Juntunen $S$, Näkkäläjärvi K. The Holistic Effects of Climate Change on the Culture, Well-Being, and Health of the Saami, the Only Indigenous People in the European Union. Curr Environ Health Rep 2018;5(4):401-17. doi: 10.1007/s40572-018-0211-2.

33. Sorensen C, Saunik S, Sehgal M, et al. Climate Change and Women's Health: Impacts and Opportunities in India. Geohealth 2018;2(10):283-97. Published 2018 Oct 17. doi:10.1029/2018GH000163

34. Burke SEL, Sanson AV, Van Hoorn J. The Psychological Effects of Climate Change on Children. Curr Psychiatry Rep 20, 35 (2018). https://doi.org/10.1007/s11920-018-0896-9

35. Swinburn BA, Kraak VI, Allender S, Atkins VJ, Baker PI, Bogard JR et al. The Global Syndemic of Obesity, Undernutrition, and Climate Change: The Lancet Commission report. Lancet (London, England), 2019;393(10173):791-846. https://doi.org/10.1016/ S0140-6736(18)32822-8

36. Gislason MK, Kennedy AM, Witham SM. The Interplay between Social and Ecological Determinants of Mental Health for Children and Youth in the Climate Crisis. Int J Environ Res Public Health 2021;18(9):4573. https://doi.org/10.3390/ijerph18094573

37. Raducu R, Soare C, Chichirez CM, Purcarea MR. Climate Change and Social Campaigns. Journal of Medicine and Life. 2020;13(4):454-7. DOI: 10.25122/jml-2020-0173. 
38. Chersich MF, Scorgie F, Wright CY, Mullick S, Mathee A, Hess J et al. Climate change and adolescents in South Africa: The role of youth activism and the health sector in safeguarding adolescents' health and education. S Afr Med J 2019;109(9):615-9. doi: 10.7196/ SAMJ.2019.v109i9.14327.

39. Islam SN, Winkel J. United Nations Climate Change and Social Inequality. No. 152. DESA Working Paper No. 152 ST/ESA/2017/ DWP/152, Department of Economic and Social Affairs, 2017. Available from: URL: https://www.un.org/esa/desa/papers/2017/ wp152_2017.pdf

40. Ahlmark N, Algren MH, Holmberg T, Norredam ML, Nielsen SS, Blom $A B$ et al. Survey nonresponse among ethnic minorities in a national health survey--a mixed-method study of participation, barriers, and potentials. Ethnicity \& Health 2015;20(6):611-32. https://doi.org/10.1080/13557858.2014.979768
41. Shea B, Knowlton K, Shaman J. Assessment of ClimateHealth Curricula at International Health Professions Schools. JAMA Netw Open 2020;3(5):e206609. doi: 10.1001/ jamanetworkopen.2020.6609.

42. Liao W, Yang L, Zhong S, Hess JJ, Wang Q, Bao J et al. Preparing the next generation of health professionals to tackle climate change: Are China's medical students ready? Environ Res 2019;168:270-7. doi: 10.1016/j.envres.2018.10.006.

43. Eckelman MJ, Sherman J. Environmental Impacts of the U.S. Health Care System and Effects on Public Health. PLoS One 2016;11(6):e0157014. doi: 10.1371/journal.pone.0157014.

44. Shrank WH, Rogstad TL, Parekh N. Waste in the US Health Care System: Estimated Costs and Potential for Savings. JAMA. 2019;322(15):1501-9. doi: 10.1001/jama.2019.13978. 